\title{
Pengaruh Model Learning Cycle $5 E$ Berbantuan Powerpoint Interaktif Terhadap Hasil Belajar IPA
}

\author{
Eling Wulandari*, Arum Ratnaningsih, Rintis Rizkia Pangestika \\ Universitas Muhammadiyah Purworejo, Indonesia \\ *Coresponding Author: elingwulandari04@gmail.com
}

Article History:

Received 2021-09-08

Revised 2022-01-02

Accepted 2022-01-22

DOI

10.31949/educatio.v8i1.1485

\begin{abstract}
This research is motivated by the low learning outcomes of students in the subjects of Natural Education. Efforts are being made to improve it by applying the 5 E learning cycle model assisted by interactive powerpoint. This study aims to determine the effect of the $5 \mathrm{E}$ learning cycle model assisted by interactive powerpoint on science learning outcomes. This research is a quantitative research with Quasi Experimental Design. The population in this study were 36 fifth grade students at Al-Madina Elementary School for the 2020/2021 academic year. Sampling using saturated sampling technique. The research sample was 18 students in the VB class as the experimental class using the $5 \mathrm{E}$ learning cycle model assisted by interactive powerpoint and 18 students in the VA class as the control class using the discovery learning model. Research data obtained from the test instrument. Data analysis used the average comparison test. The results showed that the test results after applying the 5E learning gycle model were better than the previous test results. From these results, it is concluded that there is an effect of the $5 E$ learning cycle model assisted by interactive powerpoint on student learning
\end{abstract} outcomes.

Keywords: 5E learning cycle model; interactive powerpoints; student learning outcomes; single substances and mixtures.

\begin{abstract}
Abstrak
Penelitian ini dilatarbelakangi oleh rendahnya hasil belajar siswa pada mata pelajaran Ilmu Pendidikan Alam. Upaya yang dilakukan untuk meningkatkannya adalah dengan menerapkan model learning cycle $5 \mathrm{E}$ berbantuan powerpoint interaktif. Penelitian ini bertujuan untuk mengetahui pengaruh model learning cycle $5 \mathrm{E}$ berbantuan powerpoint interaktif terhadap hasil belajar IPA. Penelitian ini merupakan penelitian kuantitatif dengan desain Quasi Experimental Design. Populasi dalam penelitian ini sebanyak 36 siswa kelas V SD Al-Madina Tahun Ajaran 2020/2021. Pengambilan sampel menggunakan teknik sampling jenuh. Sampel penelitian ialah kelas VB berjumlah 18 siswa sebagai kelas eksperimen menggunakan model learning cycle 5E berbantuan powerpoint interaktif dan kelas VA berjumlah 18 siswa sebagai kelas kontrol menggunakan model discovery learning. Data penelitian diperoleh dari instrumen tes. Analisis data menggunakan uji perbandingan rata-rata. Hasil penelitian menunjukkan hasil tes setelah pembelajaran menerapkan model learning cycle $5 E$ lebih baik dibanding hasil test sebelumnya. Dari hasil tersebut maka disimpulkan bahwa terdapat pengaruh model learning cycle 5 E berbantuan powerpoint interaktif terhadap hasil belajar siswa.

Kata kunci: model learning cycle 5E; powerpoint interaktif; hasil belajar siswa; zat tunggal dan campuran.
\end{abstract}

\section{PENDAHULUAN}

Kemajuan pendidikan telah merubah tatanan pendidikan terutama di Indonesia. Perkembangan kurikulum yang semakin signifikan membuat pemerintah semakin gencar mendorong kreativitas guru dalam mengajar. Proses mengajar tersebut nantinya akan membantu siswa dalam memahami sebuah pembelajaran yang lebih bermakna. Ketika proses belajar mengajar berlangsung, guru juga harus menggunakan model pembelajaran. Model pembelajaran tersebut berguna untuk mewujudkan atau menciptakan suasana kelas yang lebih menyenangkan dengan dibantu media pembelajaran pada proses pembelajaran. Media pembelajaran 
berfungsi sebagai alat transfer ilmu bagi siswa. Tujuan penggunaan media pembelajaran adalah supaya siswa lebih mudah dalam memahami pembelajaran yang disampaikan guru (Shalikhah, 2016), terutama pada mata pelajaran IPA. Karena, pada pembelajaran IPA, siswa akan lebih dekat dengan lingkungan. Jadi, jika guru tidak menggunakan model pembelajaran yang dibantu media pembelajaran, siswa akan kurang memahami hasil yang diperoleh.

Harapan yang diinginkan dari adanya penggunaan model pembelajaran dan media pembelajaran adalah tercapainya hasil belajar IPA yang lebih memuaskan. Hasil belajar merupakan perubahan-perubahan yang terjadi pada diri siswa, baik menyangkut pada aspek kognitif, afektif, maupun psikomotorik sebagai hasil dari kegiatan belajar (Susanto, 2016). Jadi, pemerolehan hasil belajar didapatkan setelah melakukan evaluasi pembelajaran, terutama pada pembelajaran IPA. Mata pelajaran IPA di SD menjadi mata pelajaran penting untuk mengembangkan wawasan, keterampilan dan sikap ilmiah sejak dini. Hal ini dikarenakan IPA salah satu mata pelajaran pokok dalam kurikulum pendidikan di Indonesia. Kompetensi pada sikap ilmiah terdiri dari memiliki rasa ingin tahu, jujur, logis, kritis, dan disiplin melalui IPA. Guna mencapai tujuan tersebut perlu diupayakan tindakan untuk meningkatkan minat sehingga siswa termotivasi dalam belajar sehingga diperoleh hasil belajar yang maksimal.

Namun beberapa penelitian menunjukkan bahwa hasil belajar siswa sekolah pada mata pelajaran IPA masih rendah, sehingga perlu ada upaya dari guru untuk meningkatkannya (Rahmi, 2017; Sitohang, 2018; Winantara \& Jayanta, 2017; Wulandari, 2016). Rendahnya hasil belajar siswa pada mata pelajaran IPA juga dialami oleh siswa kelas V SD Al-Madina. Berdasarkan hasil wawancara dan observasi pada bulan Oktober 2020 dengan guru, terdapat beberapa permasalahan yang ditemui oleh guru dalam pembelajaran. Permasalahan tersebut meliputi pertama, terdapat beberapa siswa yang memperoleh hasil belajar yang baik, namun masih terdapat beberapa siswa yang memperoleh nilai di bawah ketuntasan kriteria minimal (KKM) yakni sekitar 50\% siswa. Kedua, siswa belum optimal dalam menerima materi pembelajaran, walaupun guru sudah menerapkan model discovery learning, namun tidak semua siswa merespon saat disajikan suatu masalah dan menyusun dugaan sementara. Terdapat beberapa siswa memiliki pemahaman yang berbeda-beda mengenai pengetahuan yang diajarkan. Hal ini disebabkan oleh kurangnya media pembelajaran yang berfungsi untuk menjembatani proses penyampaian pengetahuan dari guru ke siswa. ketiga, kurangnya penggunaan media, sarana, dan prasarana pembelajaran pada materi zat tunggal dan campuran. Walaupun guru sudah menerapkan model discovery learning, namun dalam penggunaan media pembelajaran yang digunakan guru belum maksimal. Hal ini menyebabkan antara siswa dan guru menjadi kurang optimal, sehingga komunikasi antara guru dan siswa kurang efektif dalam mencapai tujuan pembelajaran. Keempat, siswa kurang memperhatikan proses pembelajaran mengenai materi zat tunggal dan campuran ketika proses pembelajaran. Pada saat pembelajaran siswa kerap ramai sendiri, senang berbicara sendiri, dan kurang konsentrasi. Hal ini menyebabkan pembelajaran kurang efektif karena siswa sulit untuk fokus. Sehingga guru sering dalam menegur siswa. Kelima, kurangnya pemahaman siswa dalam menyimpulkan materi pembelajaran. Hal ini berakibat pada rendahnya hasil belajar siswa pada mata pelajaran ilmu pengetahuan alam.

Mencermati permasalahan di atas, penulis mencoba mencari solusi pemecahan masalah dengan menggunakan model yang dapat mendorong siswa untuk aktif dalam pembelajaran sehingga dapat menguji hasil belajar siswa. Model pembelajaran yang digunakan peneliti adalah model Learning Cycle 5E. Model learning cycle $5 \mathrm{E}$ adalah model pembelajaran yang terdiri tahap-tahap kegiatan yang diorganisasikan sedemikian rupa sehingga siswa dapat menguasai kompetensi-kompetensi yang harus dicapai dalam pembelajaran dengan jalan berperan aktif (Rusydi et al, 2018; Senindra, 2016; Shofiah et al, 2018). Model learning cycle 5E yang digunakan ini memiliki lima tahapan yakni engage, explore, explain, elaboration, dan evaluate. Pada setiap tahapan pembelajaran ini, guru dituntut untuk menciptakan kondisi pembelajaran yang beranjak dari isu-isu sains yang relevan dengan lingkungan siswa, memicu proses disequilibrium-equilibrium (ketidakseim-bangan-seimbang) pada diri siswa serta memberi kesempatan kepada siswa untuk berinteraksi dengan orang lain agar siswa dapat membangun pengetahuannya secara utuh. Melalui model Learning Cycle 5E dapat menciptakan suatu kegiatan pembelajaran yang tidak membosankan sehingga dapat terjadi interaksi dan hubungan timbal balik yang baik antara guru dan siswa ataupun siswa dengan siswa lainnya, sehingga proses pembelajaran akan menyenangkan 
karena siswa menjadi aktif, dapat melatih siswa untuk saling berinteraksi dan kerjasama dengan teman sekelasnya (Rahayu, 2019).

Model pembelajaran ini diharapkan mendorong terwujudnya pembelajaran aktif, kreatif, inovatif, dan bermakna bagi siswa. Siswa diberi kesempatan mengeksplorasi kemampuan yang dimilikinya, sehingga memperoleh pengalaman belajar yang dapat meningkatkan pemahamannya yaitu menggunakan model pembelajaran Learning Cycle 5E. Pada pelaksanaannya, model Learning Cycle 5E akan diajarkan dengan bantuan powerpoint interaktif sebagai media pembelajaran. Tujuan penggunaan media powerpoint interaktif pada pembelajaran tesebut adalah menghidupkan suasana pembelajaran, menambah semangat, terjalinnya proses interaksi antara guru dan siswa serta ketertarikan siswa dalam belajar.

Model Learning Cycle 5E juga terbukti berhasil dalam meningkatkan hasil belajar IPA. Hal ini terungkap dari beberpa penelitian sebelumnya yang dilakukan oleh Aditya et al (2019), Astutik (2012), Mustika (2017), Setiawan et al (2017), Sugiantara et al. (2018), dan Tulak \& Buli (2019). Peneliti akan melakukan penelitian lebih lanjut dengan menggunakan model Learning Cycle 5E dengan berbantuan media pembelajaran, yaitu powerpoint interaktif. Powerpoint interaktif ini dapat menampilkan gambar-gambar tentang zat tunggal dan campuran, menyajikan tulisan-tulisan yang menarik dan siswa dapat menjawab soal-soal kuis yang sudah peneliti rancang sebelumnya pada powerpoint agar siswa aktif. Selain itu, akan digunakan animasi-animasi pada powerpoint yang akan membuat pembelajaran lebih menyenangkan. Alasan penggunaan media powerpoint interaktif ini adalah belum ada penelitian yang mencoba menggunakan model Learning Cycle 5E dengan dibantu oleh media powerpoint interaktif pada mata pelajaran IPA materi zat tunggal dan campuran. Media pembelajaran ini juga pernah menjadi fokus beberapa penelitian terdahulu dalam pembelajaran IPA, dianataranya Nurussyifa et al (2019) dan Sumiadi (2019). Model Learning Cycle 5E berbantu powerpoint interaktif diharapkan dapat membuat pembelajaran menjadi aktif, guru dan siswa dapat berinteraksi dengan baik, dan dapat meningkatkan hasil belajar siswa khususnya pada mata pelajaran IPA.

Model Learning Cycle 5E berbantu powerpoint interaktif diharapkan mampu memberikan pengaruh terhadap hasil belajar siswa dalam memahami IPA materi zat tunggal dan campuran. Sehingga dapat meningkatkan hasil belajar siswa khususnya pada mata pelajaran ilmu pengetahuan alam. Atas dasar pemikiran tersebut, penelitian ini dilakukan dengan tujuan untuk mengetahui pengaruh Model Learning Cycle 5E berbantuan Powerpoint interaktif terhadap hasil belajar IPA materi zat tunggal dan campuran siswa kelas V SD Al-Madina Tahun Ajaran 2020/2021.

\section{METODE PENELITIAN}

Jenis penelitian ini adalah penelitian kuantitatif. Desain penelitian yang digunakan adalah Quasi Experimental Design. Rancangan yang digunakan adalah Nonequivalent Control Group Design. Rancangan ini melibatkan dua kelompok, yaitu kelompok kontrol dan kelompok eksperimen. Kelas VA adalah kelompok kontrol menggunakan model Discovery Learning dan kelas VB adalah kelompok eksperimen yang akan diberi perlakuan model Learning Cycle 5E yang dibantu dengan powerpoint.

Populasi dalam penelitian ini sebanyak 36 siswa kelas V SD Al-Madina Tahun Ajaran 2020/2021. Penentuan kelas kontrol dan kelas eksperimen penelitian ini menggunakan teknik pengambilan sampling jenuh. Sampling jenuh adalah teknik penentuan sampel apabila semua seluruh populasi dijadikan sebagai sampel (Jakni, 2016). Sampel yang diambil dari populasi penelitian yaitu siswa kelas V SD Al Madina Purworejo. Kelas VA sebagai kelas kontrol dan kelas VB sebagai kelas eksperimen. Sampel yang digunakan dengan pertimbangan bahwa sebagai kelas kontrol dan eksperimen sama-sama satu tingkat jenjang pendidikan dan menerima materi pembelajaran yang sama, sedangkan kelas V SD Negeri Pekutan dijadikan sebagai kelas uji coba instrumen test penelitian.

Pengumpulan data yang digunakan dalam penelitian ini adalah menggunakan teknik tes dan teknik nontes. Teknik tes ini digunakan peneliti untuk mengukur hasil belajar siswa dan dilakukan sebelum dan sesudah perlakukan. Pada penelitian ini tes digunakan untuk mengetahui pengaruh model Learning Cycle 5E berbantuan powerpoint interaktif terhadap hasil belajar IPA materi zat tunggal dan campuran siswa kelas V SD Al-Madina. Tes yang digunakan ialah tes objektif. Peneliti menggunakan tes dengan bentuk pilihan ganda. 
Penelitian ini menggunakan teknik nontes yang digunakan untuk memperoleh infomasi hasil belajar atau informasi tentang siswa antara lain wawancara dan dokumentasi. Peneliti hanya menggunakan pedoman wawancara yang berupa garis besar permasalahan yang akan ditanyakan. Peneliti bertanya kepada guru untuk mencari tahu kondisi kelas saat pembelajaran dan permasalahan yang dialami siswa atau guru dalam kegiatan pembelajaran.

Data yang terkumpul selanjutnya dianalisis untuk membuktikan ada tidaknya pengaruh model Learning Cycle 5E berbantuan powerpoint interaktif terhadap hasil belajar IPA materi zat tunggal dan campuran pada siswa kelas V SD Al-Madina dan perbedaan hasil belajar siswa yang diajarkan dengan model Learning Cycle 5E berbantuan powerpoint interaktif dengan siswa yang tidak diajar dengan model Learning Cycle 5E berbantuan powerpoint interaktif yang terpilih sebagai kelompok eksperimen dan kelompok kontrol.

\section{HASIL DAN PEMBAHASAN}

Penelitian ini dilakukan bertujuan untuk mengetahui ada tidaknya pengaruh antara penggunaan model learning gycle $5 E$ berbantuan powerpoint interaktif terhadap hasil belajar siswa. Data yang dikumpulkan adalah data hasil tes siswa sebelum dan sesudah dilaksanakan perlakukan, yaitu model learning yycle $5 \mathrm{E}$ berbantuan powerpoint interaktif. Data tersebut diolah dengan teknik t-test setelah data dinyatakan normal dan homogen. Hasil analisa uji-t menggunakan bantuan SPSS versi 21 dapat dilihat pada tabel 1.

Tabel 1. Uji Paired Sampel Test

\begin{tabular}{|c|c|c|c|c|c|c|}
\hline & & \multicolumn{2}{|c|}{ Paired Differences } & \multirow[t]{2}{*}{$t$} & \multirow[t]{2}{*}{$d f$} & \multirow{2}{*}{$\begin{array}{l}\text { Sig. (2- } \\
\text { tailed) }\end{array}$} \\
\hline & & Mean & Std. Deviation & & & \\
\hline \multirow{2}{*}{ Pair 1} & Pretest Eksperimen-Posstest & -16.889 & 6.220 & -11.519 & 17 & .000 \\
\hline & Eksperimen & & & & & \\
\hline Pair 2 & Pretest Kontrol - Posstest Kontrol & -15.778 & 6.358 & -10.529 & 17 & .000 \\
\hline
\end{tabular}

Berdasarkan hasil tabel pengujian paired sampel test terlihat bahwa pair 1 pretest eksperimen dengan posstest eksperimen menunjukkan nilai signifikansi (2 tailed) sebesar 0,000 dan pair 2 pretest kontrol dengan posstest kontrol memiliki nilai signifikansi (2 tailed) sebesar 0,000. Hasil penelitian baik kelas eksperimen maupun kelas kontrol memiliki nilai signifikasi (sig) $=0,000$. Hal ini menunjukkan bahwa pada taraf signifikansi $5 \%(\alpha=0,05)$. Nilai sig $(2$ tailed $)<0,05$. Maka $\mathrm{H}_{a} 1$ diterima dan $\mathrm{H}_{0} 1$ ditolak. Jadi, ada pengaruh antara pengaruh model Learning Cycle 5E berbantuan powerpoint interaktif terhadap hasil belajar IPA materi zat tunggal dan campuran siswa kelas V SD-Al Madina tahun ajaran 2020/2021.

Tabel 2. Paired Sampel Statistik

\begin{tabular}{llcccc}
\hline & Mean & N & Std. Deviation & $\begin{array}{c}\text { Std. Error } \\
\text { Mean }\end{array}$ \\
\hline \multirow{2}{*}{ Pair 1 } & & & & 7.029 & 1.657 \\
& Pretest Eksperimen & 72.67 & 18 & 4.973 & 1.172 \\
Pair 2 & Pretest Kontrol & 89.56 & 18 & 4.314 & 1.017 \\
& Posstest Kontrol & 71.56 & 18 & 6.325 & 1.491 \\
\hline
\end{tabular}

Guna mengetahui seberapa besar pengaruh antara kelas eksperimen dan kelas kontrol, dapat dilihat nilai mean pada tabel 2. Tabel 2 menunjukkan nilai rata-rata (mean) pretest eksperimen sebesar 72,67 dan nilai posstest eksperimen sebesar 89,56 artinya terdapat peningkatan hasil belajar sebesar 16,89.

Guna mengetahui perbedaan hasil belajar siswa pengaruh model learning cyclel $5 \mathrm{E}$ berbantuan powerpoint terhadap hasil belajar dengan uji independent sampel test yang dilakukan terhadap data posstest kelas eksperimen dengan data posstest kelas kontrol. Hasil perhitungan uji independent sampel test dengan bantuan spss versi 21 dapat dilihat pada tabel 3. 
Tabel 3. Independent Sampel Test

\begin{tabular}{|c|c|c|c|c|c|c|c|}
\hline & & \multicolumn{2}{|c|}{$\begin{array}{c}\text { Levene's Test for } \\
\text { Equality of Variances }\end{array}$} & \multicolumn{4}{|c|}{ t-test for Equality of Means } \\
\hline & & $\mathrm{F}$ & Sig. & $\mathrm{t}$ & df & $\begin{array}{l}\text { Sig. }(2- \\
\text { tailed) }\end{array}$ & $\begin{array}{c}\text { Mean } \\
\text { Difference }\end{array}$ \\
\hline Hasil & $\begin{array}{l}\text { Equal variances } \\
\text { assumed }\end{array}$ & 1.168 & .287 & 1.172 & 34 & .249 & 2.222 \\
\hline $\begin{array}{l}\text { Belajar } \\
\text { Siswa }\end{array}$ & $\begin{array}{l}\text { Equal variances not } \\
\text { assumed }\end{array}$ & & & 1.172 & 32.208 & .250 & 2.222 \\
\hline
\end{tabular}

Berdasarkan tabel 3 setelah dilakukan pengujian independent sampel test equal variances assumed data homogen dalam uji prasarat terlihat bahwa nilai sig ( 2 tailed) sebesar 0,249. Sig ( 2 tailed) 0,249 >0,005 maka dapat disimpulkan bahwa tidak terdapat perbedaan hasil belajar siswa antara model learning cycle $5 E$ berbantuan powerpoint interaktif dengan model discovery learning terhadap hasil belajar siswa IPA materi zat tunggal dan campuran siswa kelas V SD Al-Madina. Selain dengan membandingkan nilai signifikansi, kita dapat menguji menggunakan nilai t pada tabel di atas, diketahui bahwa nilai thitung dalam penelitian ini sebesar 1,172 dengan $\mathrm{n}=34$, sedangkan $\mathrm{t}_{\text {tabel }}$ untuk $\mathrm{n}=34$ ialah sebesar 2,032. Sehingga nilai $\mathrm{t}_{\text {hitung }}=1,172<\mathrm{t}_{\text {tabel }}=2,032$ berdasarkan data di atas maka dapat disimpulkan bahwa $\mathrm{H}_{2}$ ditolak dan $\mathrm{H}_{0}$ diterima.

Dengan demikian secara keseluruhan bahwa hasil belajar model learning gycle $5 E$ berbantuan powerpoint interaktif sama baiknya dengan siswa yang diajar dengan discovery learning pada materi zat tunggal dan campuran. Dengan kata lain, seperti halnya discovery learning, model learning cycle $5 E$ berbantuan powerpoint interaktif juga berhasil meningkatkan hasil belajar siswa dalam mata pelajaran IPA. Hasil penelitian ini sesuai dengan penelitian yang dilakukan oleh Aditya et al (2019), Astutik (2012), Mustika (2017), Setiawan et al (2017), Sugiantara et al. (2018), dan Tulak \& Buli (2019) yang menyatakan bahwa model Learning Cycle 5E dapat meningkatkan hasil belajar pada mata pelajaran IPA. Penggunaan powerpoint interaktif juga menjadikan pembelajaran lebih menarik bagi siswa sehingga siswa memiliki minat yang besar dalam belajar IPA.

\section{KESIMPULAN}

Berdasarkan hasil penelitian yang telah dilaksanakan di SD Al-Madina tahun ajaran 2020/2021, dapat disimpulkan bahwa terdapat pengaruh model learning cycle $5 \mathrm{E}$ berbantuan powerpoint interaktif terhadap hasil belajar IPA materi zat tunggal dan campuran siswa kelas V SD Al-Madina tahun 2020/2021. Hasil belajar IPA menggunakan model learning cycle 5E berbantuan powerpoint interaktif sama-sama baik dengan hasil belajar siswa yang menerapkan model discovery learning.

\section{DAFTAR PUSTAKA}

Aditya, I. K. D., Sumantri, M., \& Astawan, I. G. (2019). Pengaruh Model Pembelajaran Learning Cycle (5e) Berbasis Kearifan Lokal Terhadap Sikap Disiplin Belajar Dan Hasil Belajar IPA Siswa Kelas IV SD Gugus V Kecamatan Sukasada. Jurnal Pendidikan Multikultural Indonesia, 2(1), 43-54.

Astutik, S. (2012). Meningkatkan hasil belajar siswa dengan model siklus belajar (learning cycle 5e) berbasis eksperimen pada pembelajaran sains di sdn patrang i jember. Jurnal Ilmu Pendidikan Sekolah Dasar, 1(2), 143-153.

Mustika, D. (2017). Pembelajaran Menggunakan Model Learning Cycle 5E untuk Meningkatkan Hasil Belajar IPA di Sekolah Dasar. Jurnal Handayani Pgsd Fip Unimed, 7(2), 1-8.

Nurussyifa, A. M., Djumhana, N., \& Saefudin, A. (2019). Perbedaan Hasil Belajar Ipa Siswa Sd Berdasarkan Penggunaan Multimedia Interaktif Berbasis Powerpoint. Jurnal Pendidikan Guru Sekolab Dasar, 4(3), 45-56.

Rahayu, S. (2019). Penerapan Model Pembelajaran Learning Cycle-5E Dalam Pembelajaran IPA. Jawa Timur: Beta Aksara. 
Rahmi, F. (2017). Penerapan Pendekatan Saintifik Sebagai Upaya Meningkatkan Hasil Belajar IPA Siswa Kelas IV SDN 19 Koto Tinggi. Jurnal Inovasi Pendidikan dan Pembelajaran Sekolah Dasar, 1(2).

Rusydi, A. I., Hikmawati, H., \& Kosim, K. (2018). Pengaruh Model Learning Cycle 7E terhadap Kemampuan Berpikir Kritis Peserta Didik. Jurnal Pijar Mipa, 13(2), 124-131.

Senidra, H. (2016). Pengaruh Modelpembelajaran Learning Cycle 5e Terhadap Hasil Belajar Fisika Siswa Kelas X Man Prabumulih. Jurnal Inovasi Dan Pembelajaran Fisika, 3(1), 66-72.

Setiawan, I. W. P., Suartama, I. K., \& Putri, D. A. W. M. (2017). Pengaruh Model Pembelajaran Learning Cycle 5e Berbantuan Mind Mapping Terhadap Hasil Belajar Matematika. Mimbar PGSD Undiksha, 5(2).

Shalikhah, N. D. (2016). Pemanfaatan aplikasi Lectora Inspire sebagai media pembelajaran interaktif. Cakrawala: Jurnal Studi Islam, 11(1), 101-115.

Shofiah, S., Lukito, A., \& Siswono, T. Y. E. (2018). Pembelajaran learning cycle 5e berbasis pengajuan masalah untuk meningkatkan hasil belajar siswa kelas X pada topik trigonometri. Kreano, Jurnal Matematika Kreatif-Inovatif, 9(1), 54-62.

Sitohang, J. (2018). Penerapan Metode Tanya Jawab Untuk Meningkatkan Hasil Belajar Ipa Pada Siswa Sekolah Dasar. Suara Guru, 3(4), 681-688.

Sugiantara, I. P., Kusmariyatni, N., \& Margunayasa, I. G. (2013). Pengaruh Model Pembelajaran Learning Cycle 5E Terhadap Hasil Belajar IPA Siswa Kelas V di Gugus VII Kecamatan Buleleng. MIMBAR PGSD Undiksha, 1(1).

Sumiadi, R. (2019). Penerapan Multimedia Interaktif Microsoft Powerpoint untuk Meningkatkan Hasil Belajar IPA Siswa Kelas IV MI Maraqitta'limat. JISIP (Jumal Ilmu Sosial dan Pendidikan), 3(1).

Susanto, A. (2016). Teori Belajar dan Pembelajaran di Sekolah Dasar. Jakarta: Kencana.

Tulak, T., \& Buli, S. (2019). Meningkatkan Hasil Belajar IPA Melalui Model Pembelajaran Learning Cycle 5E Pada Siswa Kelas IV SDN 101 Makale 4 Kecamatan Makale Kabupaten Tana Toraja. Elementary Journal, 1(2), 41-50.

Winantara, I. D., \& Jayanta, I. N. L. (2017). Penerapan model pembelajaran TPS untuk meningkatkan hasil belajar IPA Siswa kelas V SD No 1 Mengwitani. Jurnal Ilmiah Sekolah Dasar, 1(1), 9-19

Wulandari, F. (2016). Penerapan model pembelajaran inkuiri terbimbing untuk meningkatkan hasil belajar ipa siswa sekolah dasar. PEDAGOGLA: Jurnal Pendidikan, 5(2), 267-278.. 